\title{
Russian Policy in the South Caucasus
}

\author{
Vitaly V. Naumkin ${ }^{1}$
}

The South Caucasus is of interest to Russia both in terms of ensuring Russia's security and in terms of its economy. Among the many factors determining the importance of this region one may single out the following:

- It borders on the North Caucasus, which generates grave internal threats to Russia's security.

- It separates Russia from its major southern partners, Turkey and Iran.

- It has a high level of instability, with some serious unsettled internal conflicts. There is also potential for conflict in relations between South Caucasian states and with their southern neighbors.

- The states of the region play an important role in the development of the mineral resources of the Caspian Basin.

- Global and regional powers, and other states as well, are paying increasing attention to the region.

Russia's policy towards the South Caucasus has undergone significant changes in the 1990s, and can hardly be characterized as consistent. Nevertheless, Moscow has through all these years been deeply involved in emerging processes in the South Caucasus, and has been afraid of being crowded out of them and of its interests being infringed upon due to the increased presence of third-party actors in the region. This motivation has exerted a constant force on Russia's behavior. Today, facing huge difficulties in search of a way out of the Chechen conflict, Russia is especially interested in this region that is both stable and friendly to it, a reason which overrides the temptation to deploy risk factors menacing the South Caucasian states (Azerbaijan, Armenia, and Georgia) in the interests of Russia.

\section{Russia's Changing Position}

The existence of long-standing interethnic conflicts (Georgian-Abkhazian, Armenian-Azeri, or Karabakh, Georgian-South Ossetian, Lezgin, and others) feeds into strong Russian security concerns. Russia made a significant contribution to the settlement of these conflicts, though the final resolutions have not been yet achieved. Russian diplomacy brokered the ceasefire agreement between Baku and Karabakh, its peacekeepers together with Georgian and Ossetian ones guard

\footnotetext{
${ }^{1}$ Vitaly V. Naumkin is a Professor of Political Science and the President of the International Center for Strategic and Political Studies, Moscow, Russia.
} 


\section{THE QUARTERLY JOURNAL}

the cease-fire regime in the South Ossetia, and its peacekeepers are playing the same role in Abkhazia.

The triad by means of which Russia was safeguarding the interests of its security in the 1990s in both the South Caucasus and Central Asia-military bases, defense of the CIS external borders, peacekeepers - had by the end of that decade started to crack. The concentration of Russian forces in Transcaucasia was cut down, while the general cutback in the armed forces affected the wider military presence in the area. In March 1999, the Defense Committee of the Georgian parliament demanded the pullback from Georgia of two of the four remaining Russian bases-in Bombora (Abkhazia) and Vaziani (near Tbilisi). ${ }^{2}$ During the OSCE summit in Istanbul in October 1999, such an agreement was reached between Georgia and the Russian Federation. In the same year, Georgia, along with Uzbekistan and Azerbaijan, did not renew their membership in the Collective Security Treaty (signed on May 15, 1992). The Russian peacekeepers stationed in Abkhazia have come under attack from certain Georgian circles. These circles have tried to impose on the peacekeepers the fulfillment of functions not stipulated by their mandate, namely, to ensure the security of returning refugees.

Russia's military presence evoked flaccid complaints in Washington and other NATO capitals. The U.S. and NATO, for their part, while relying on Turkey, were actively drawing the countries of the region into their orbit. Azerbaijan and Georgia have been increasingly viewed by many as the Western strongholds in the region, whereas Armenia, pursuing active military-technological cooperation with Russia on a treaty basis, has been regarded as Russia's strategic ally.

As far as the Caspian oil resources are concerned, Russia expressed interest in having its share of them, and to procure the transit of this oil via its territory. In the first half of the 1990s, Russia's and Azerbaijan's views on the issue of the exploitation of the Caspian Sea and its legal status were at odds, but after President's Putin's visit to Baku in the beginning of 2001, Azerbaijan came around to the position of Russia and Kazakhstan. In July 1998, Presidents Yeltsin and Nazarbaev agreed to divide the Caspian seabed into sectors, leaving the waters and the air space in the joint possession of the littoral states.

Russia understands the common interest of the South Caucasian states and the oil consumers in the safe delivery of the Caspian oil to the world market. But Moscow has legitimate concerns about the environmental consequences of the exploitation of oil reserves, especially given the vulnerability of the Caspian biological resources, especially the sturgeon, seal, and rare bird species. In the view of Geoffrey Kemp, "The Caspian is particularly vulnerable from the ecological standpoint to oil spills and other related sources of pollution. ${ }^{3}$ Moscow

\footnotetext{
${ }^{2}$ Nezavisimaya gazeta, March 19, 1999, 5.

${ }^{3}$ Geoffrey Kemp, Energy Superbowl: Strategic Politics in the Persian Gulf and Caspian Basin (Washington, D.C.: Nixon Center for Peace and Freedom, 1997), 33
} 
also viewed as a risk factor the opposition to the advancement of its interests on the part of the U.S., who undertook to support the new republics in the region in strengthening their sovereignty, but who understood this primarily as protecting them from Russia. According to one of the leading American analysts, the "leaders and peoples of Central Asia and the Caucasus see in Russia the main threat to their independence."

Russia is aware of the inevitability of the diversification of transit routes for the Caspian oil to the world markets. But Moscow is not in favor of supporting the construction of pipelines for merely political purposes. The U.S. support for the construction of Baku-Ceyhan oil pipeline, one that was not considered by many oil companies as economically feasible, was interpreted in Moscow as being directed against Russia's interests that lay in directing the transit of oil via its territory. Despite its skepticism towards the commercial value of the project, Russia demonstrated its desire to cooperate with those who favor this route. One of the leading Russian oil companies, LUKoil, may agree to participate in the construction of this pipeline.

Given the multiplicity of risks and challenges in the South Caucasus, the question arises of the role of military force in protecting stability and securing the economic interests of all local, regional, and global players. The calls for the demilitarization of the Caspian from some of the littoral capitals (Baku and Tehran) were viewed by Russia as an attempt to weaken its already vulnerable southern flank from deterring the potential threats that abound there.

The economic interest was exerting its influence on the political and military interests. The fact that about two million Azeris work in Russia, their remittances forming a substantial part of the country's income, makes the Azeri leadership interested in better relations with Moscow. This partially explains why President Heydar Aliyev cooperated with Russia in preventing the use of Azerbaijan's territory by the Chechen rebels.

That was not the case in Georgia. Moscow strongly criticized the Georgian government for allowing the transit of mercenaries, weapons, and money through Georgian territory to Chechnya and for harboring terrorists, who penetrated into Georgia with the Chechen refugees. But Georgian President Eduard Shevardnadze demonstrated no willingness to undertake measures against these elements.

\section{The United States' Growing Involvement}

The events that followed the terrorist attacks on New York and Washington changed the whole climate in the relationship between Russia and the West. Russia strongly supported the U.S.-led anti-terrorist campaign and showed its understanding of the increased American military presence in Central Asia.

\footnotetext{
${ }^{4}$ Laurent Ruseckas, Caspian Studies Program Experts Conference Report. Succession and LongTerm Stability in the Caspian Region (Cambridge, MA: Harvard University, October 1999), 109.
} 


\section{THE QUARTERLY JOURNAL}

The abrupt changes in the security environment in the South Caucasus caused by the arrival in Georgia of U.S. military advisors at the end of February 2002 have led to a stormy debate in Russia. The appearance of military instructors from the U.S. in Tbilisi was not expected by the Russian leadership although, according to American officials, it was as early as the end of the last year, within the framework of the joint working group on Afghanistan, that the American side informed the Russians of the existence of the preparations and supply program for Georgia. Nevertheless, the fact that President Shevardnadze did not find it necessary to inform Moscow about the planned arrival of American military advisors in Tbilisi came as a shock to the Russian leadership. This was attested to, in particular, by the public pronouncement by Vladimir Putin made during the informal CIS summit that took place in Almaty on March 1-2, 2002. Even given this response, Russia's president also emphasized that Georgia has the right to apply for assistance to whatever countries it deems necessary to do so. Russian Federation Foreign Minister Igor Ivanov spoke of Russia's "concerns that the direct involvement of the U.S. military in actions to combat terrorists in Georgia may further aggravate the situation in the region. ${ }^{5}$

Significantly, President Shevardnadze, explaining his position, stressed that the U.S. had helped Georgia to create border guard troops, and would now help in creating and training "antiterrorist groups," "that not any other country can do. ${ }^{6}$ Both Georgian and American representatives pointed out that the question was not about sending a military force to Georgia that would directly participate in an antiterrorist operation, but only about sending instructors to train Georgian special forces.

In the process, the Pankisi Gorge at the Georgian border with Chechnya, where there are many armed rebels among the Chechen refugees, was mentioned as an object of a possible operation of the Georgian special forces. In this connection, the Russian authorities have expressed satisfaction with Tbilisi's recognition of the fact that there are Chechen rebels in Pankisi (this had earlier been denied)? Therefore, the eventual prospect of the liquidation of the rebel base in Georgia and of blocking the supply channels of Chechen separatists through the South Caucasus even corresponds to Russian interests.

However, analysts in Russia express doubt that it is the Pankisi Gorge that will become the target of a future operation for the Georgian troops. There are fears that, with the support of the U.S. military, the Georgian army may try to reestablish Tbilisi's control over Abkhazia, with whose population the entire North Caucasian region, along with a section of the Russian political elite, traditionally sympathize. To start an armed operation, it is enough to provoke terrorist acts against Geor-

\footnotetext{
${ }^{5}$ Izvestia, March 1, 2002.

${ }^{6}$ The Russian TV's ORT program, March 1, 2002.

${ }^{7}$ Ibid.
} 
gians on Abkhazian territory after having previously redeployed or forced out a part of the Chechen rebels there. Dmitri Rogozin, head of the State Duma Committee on International Affairs, has said that he has information on the intention of the Georgian leaders to "make an arrangement with the Chechen rebels," and, "possibly together with the Americans, ... [to] squeeze the mercenaries out of the Pankisi Gorge."

The Russian press even published articles about a possible "U.S. offensive" against all four unrecognized republics (Nagorno-Karabakh, South Ossetia, Abkhazia, and Transdniestria), three of which are situated in the South Caucasus. Having assisted the Transcaucasian states in regaining control over their mutinous republics, the U.S., in the opinion of the authors of such forecasts, will ensure the stability of the regimes that would henceforth be under U.S. control.

In any case, Russia expects that Azerbaijan will become the next recipient of U.S. military assistance. There, the threat of destabilization is growing with the relentless approach of change in the country's top leadership. This may induce the Americans to take action, especially in view of their substantial petroleum interests. Just as in the case of Georgia, Russia can do little to oppose this, and will hardly think it necessary to enter into a confrontation with the U.S. However, as distinct from Georgia, in Azerbaijan the Russian leadership has recently managed to achieve a certain consolidation of its positions, having considerably improved relations with that state.

In connection with the active U.S. "breakthrough" in the South Caucasus, Moscow's traditional strategic alliance with Yerevan can also be rendered somewhat vulnerable. Armenia, to a no lesser degree than other Transcaucasian republics, which is interested in receiving economic, political, and other kinds of aid from the West, has already been given to understand that it will not be excluded from Washington's sphere of attention. Already in early March 2002, there were media reports on the (so far) modest American military aid of $\$ 4.5$ million promised to Yerevan for combating terrorism, as well as on the first steps in building cooperation in that field.

If Russia's executive authority showed restraint in reacting to the events in Georgia, in parliamentary circles the reaction was sharper. A number of deputies of the State Duma proposed to adopt a statement on Abkhazia and South Ossetia in the event that the American military contingents start arriving in Georgia after all. According to Rogozin, "In the event of Georgia's break-up, Russia has the right to recognize the sovereignty and independence of Abkhazia and South Ossetia and start building interstate relations with them." However, such a statement had no chance of receiving the support of the Duma majority loyal to the president,

\footnotetext{
${ }^{8}$ Armen Khanbabian, "Nepriznannoi 'chetverke' ugrozhaet smertel'naya opasnost"' (Fatal danger threatens the unrecognized "Four"), Nezavisimaya gazeta, March 2, 2002.
} 
as this would enmesh Russia in a conflict with the West, and could also entail a reciprocal recognition of the independence of Chechnya.

Nevertheless, the president of unrecognized Abkhazia Vladislav Ardzinba addressed a request to the Russian leadership for the establishment of "associated relations" with Abkhazia, a status allowed by the Abkhazian constitution. Information has appeared on a referendum to be held in Abkhazia in the near future on the question of amending the constitution to include a clause allowing the republic's incorporation into Russia.

\section{The 'Strategic Uncertainty'}

On the whole, the increased American presence in the South Caucasus has created a situation of "strategic uncertainty" concerning Russia's relations with the countries of this region. It is not clear, as yet, how the Americans, and possibly other Western players, will be received on the local scene. If the news which has appeared in the press on the alleged U.S. intention to build an electronic surveillance station in Georgia - similar to the one Russia had in Lurdes in Cuba-proves to be true, it will give the Americans an opportunity to maintain surveillance over communications not only in Iran (and this is undoubtedly one of their main objectives), but also in Russia's southern regions.

This situation of "strategic uncertainty" will probably last for some time. Russia will closely watch the events, and will probably wish to revitalize bilateral relations with the Transcaucasian states of Armenia, which is still in need of Moscow's support, and Azerbaijan, with whom relations have received a positive impetus during the recent successful visit to Russia by President Heydar Aliyev.

So far, it is not clear what influence the U.S. incursion into the security domain of the southern zone of the CIS as a whole and the Southern Caucasus in particular will have on the fate of collective mechanisms and, first of all, on the Collective Security Treaty, along with the CIS itself. It is hard to imagine what fate awaits the Russian peacekeepers in the Georgian-Abkhazian conflict zone. If until recently they served as the only force able to maintain the ceasefire in that zone, it is not inconceivable that under new conditions Georgia might try to secure the replacement of the Russians by peacekeepers from other states. In this case, Tbilisi will certainly try to impose on them the performance of police functionsto ensure the return of the Georgian refugees to the Gali district. This, in turn, may cause an outbreak of violence that, in the end, could be used as an occasion for the restoration of Tbilisi's sovereignty over Abkhazia by means of military force.

In the near future, Russia has to establish a system of priorities and develop a precise strategy concerning the South Caucasian region and each of the three South Caucasian states. In view of the new circumstances, it will also be necessary for Moscow to analyze its peacekeeping role in the ethnopolitical conflicts in the region. Russia's position in the South Caucasus has generally become aggravated, as the security system it has been building at the perimeter of its southern borders 
No.3, SEPTEMBER 02

has seriously cracked. However, the prospect of building close relations between Moscow and the South Caucasian states is still viable. 


\section{Bibliography}

Kemp, Geoffrey. Energy Superbowl: Strategic Politics in the Persian Gulf and Caspian Basin . Washington, D.C.: Nixon Center for Peace and Freedom, 1997.

Ruseckas, Laurent. Caspian Studies Program Experts Conference Report. Succession and Long- Term Stability in the Caspian Region . Cambridge, MA: Harvard University, October , 1999. 